\title{
Productivity and Water-Use Efficiency of Sorghum in Rainfed Regime in the Semi-Arid Region of Brazil
}

\section{Erialdo de Oliveira Feitosa, Antonio Flávio Batista Araújo, Calorine Maria Bayma Oliveira, Fernando Bezerra Lopes, Eunice Maia de Andrade}

Department Agricultural Engineering, Federal University of Ceará, Campus of Pici, Fortaleza, Brazil

Email: erialdofeitosa5@gmail.com

How to cite this paper: de Oliveira Feitosa, E., Araújo, A.F.B., Oliveira, C.M.B., Lopes, F.B. and de Andrade, E.M. (2017) Productivity and Water-Use Efficiency of Sorghum in Rainfed Regime in the Semi-Arid Region of Brazil. American Journal of Plant Sciences, 8, 2133-2148.

https://doi.org/10.4236/ajps.2017.89143

Received: July 12, 2017

Accepted: August 6, 2017

Published: August 9, 2017

Copyright $\odot 2017$ by authors and Scientific Research Publishing Inc. This work is licensed under the Creative Commons Attribution International License (CC BY 4.0).

http://creativecommons.org/licenses/by/4.0/

\begin{abstract}
Sorghum has become ever more prominent on the global energy scene, with studies in the area becoming extremely important. Agricultural production in the semi-arid region of the Brazilian Northeast is intrinsically dependent on rainfall in the region. However, on both inter- and intra-annual scales, the rainfall regime is quite irregular. The aim of this study was to evaluate the productivity of sorghum grown under a rainfed regime, and the water-use efficiency of crops in the semi-arid region of the northeast of Brazil. The work was carried out in the city of Tabuleiro do Norte in the semi-arid region of the State of Ceará. Mean productivity of the sorghum was $919.42 \mathrm{~kg} \cdot \mathrm{ha}^{-1}$, with maximum values being recorded for lot $02\left(1032 \mathrm{~kg} \cdot \mathrm{ha}^{-1}\right)$, lot 03 (1102 $\left.\mathrm{kg} \cdot \mathrm{ha}^{-1}\right)$, lot $04\left(2143 \mathrm{~kg} \cdot \mathrm{ha}^{-1}\right)$ and lot $12\left(1367 \mathrm{~kg} \cdot \mathrm{ha}^{-1}\right)$. The greatest value for water-use efficiency, $1.13 \mathrm{~m}^{3} \cdot \mathrm{kg}^{-1}$, was found for lot 04 , while the smallest value, $4.83 \mathrm{~m}^{3} \cdot \mathrm{kg}^{-1}$ was seen in lot 02 . It was found that the low productivity of sorghum in a rainfed regime shows that the lack of success in production systems in semi-arid regions is not due to the total amount of rainfall, but rather the spatial and temporal distribution of the rains, as well as the occurrence of hot, dry spells. Furthermore, it can be seen that the best ratio of grain production to water demand shows a strong correlation with the distribution of water throughout the cycle, and not only with the total volume.
\end{abstract}

\section{Keywords}

Production, Rainfed Agriculture, Sorghum bicolor L.

\section{Introduction}

Sorghum (Sorghum bicolor L.) is the fifth most-cultivated cereal in the world. 
Currently, more than $35 \%$ is grown directly for human consumption [1]. According to [2], it is the staple food for more than 500 million people living mainly in Africa and Asia. In these countries, it supplies $70 \%$ of the daily calorie intake, thus playing a fundamental role in food safety [2] [3] [4].

Global production of sorghum for 2016/2017, according to the United States Department of Agriculture [5], was 63.9 million tonnes. The United States leads world production with a little over 10 million tonnes, in second place is Mexico, with more than 7.0 million tonnes, and in third place, Nigeria, with around 6.0 million tonnes.

Brazilian production in the $2015 / 2016$ season was $1,378,700$ tonnes, according to data from the National Company for Supply [6]. The Central-West and Southeast of Brazil are noteworthy for their production of 780,200 tonnes and 439,200 tonnes respectively. The Northeast, equal to $72 \%$ of the semi-arid region of Brazil, had a production of 96,500 tonnes.

According to [7], the semi-arid region of the Brazilian Northeast has an agricultural production which is intrinsically dependent on the rainfall in the region, but this regime is quite irregular, both on inter- and intra-annual scales. This uncertainty exposes the rural population, and agricultural production in particular, to a high level of vulnerability to the climatic conditions of the region. As an integral part of the semi-arid region, the State of Ceará is also characterised by high spatial and temporal variability in the rainfall regime [8]. Despite this, agricultural production in the state is based on rainfed agriculture [9].

Data from the National Institute for the Semiarid [10] show that the semiarid region of the Brazilian Northeast has around 23.8 million inhabitants, and is extremely vulnerable to variations in climate and the frequency of the droughts that mainly affect family farming, which consists for the most part of plantations under a rainfed system.

According to [11], approximately $56 \%$ of the total cultivated area in India is under rainfed agriculture. The importance of rainfed agriculture can be evaluated by the fact that it contributes to $40 \%$ of the country's food production.

Therefore, the question of the development of rainfed agriculture is critically important, due to growth and its implications for the subsistence security of a significant number of people living in the semi-arid region of the Northeast. Given the above, the aim here was to analyse the productivity and water-use efficiency of sorghum in a rainfed regime in the semi-arid region of Brazil.

\section{Material and Methods}

\subsection{Location of the Study Area}

The research was carried out in an area of the semi-arid region of Brazil (Figure 1) located in the Settlement of Lagoa Grande, which is supported by the National Institute for Colonisation and Agrarian Reform-INCRA. This has a total area of 2992.57 ha, where there are 92 farming families, and a total population of 392 inhabitants. The area of the settlement under rainfed agriculture is inserted 


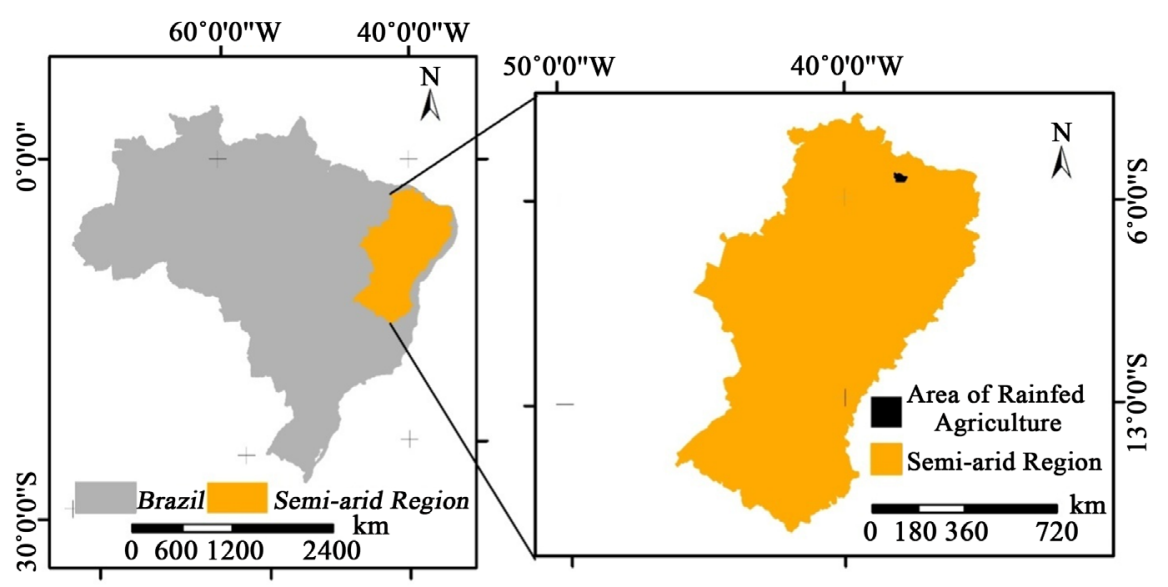

Figure 1. Location of the semi-arid region of Brazil and the area of rainfed agriculture.

in the Chapada do Apodi located geographically at $5^{\circ} 20^{\prime}$ latitude and $38^{\circ} 0^{\prime}$ longitude, at a distance of $30 \mathrm{~km}$ from the town of Tabuleiro do Norte, Ceará, Brazil.

The study was carried out with 12 producers, growing rainfed grain sorghum in an area equal to 138 ha of the universe of 250 ha used for agriculture in the above settlement, the study area being divided into 12 lots.

Data for the survey were obtained from spreadsheets and through interviews with the representatives of the family production units, where each producer represented one sample unit of the productivity of the rainfed sorghum.

\subsection{Characterisation of Soil and Climate}

The climate of the region is hot semi-arid, with average monthly temperatures greater than $18^{\circ} \mathrm{C}\left(\mathrm{BSw}^{\prime} \mathrm{h}^{\prime}\right)$. The average annual rainfall is $790 \mathrm{~mm}$, in a unimodal regime, with maximum rainfall concentrated from February to April. The predominant vegetation represents deciduous spiny forest, dense shrub-like caatinga, open brush-like caatinga, and mixed dicot-palm forest [12].

Other characteristics of the climate in the region can be seen in Table 1, comprising the mean values of a historical series from 2000 to 2016.

The soil in the area of rainfed agriculture of the Lagoa Grande Settlement located in the Chapada do Apodi is classified as a Red-Yellow Eutrophic Cambisol, deep, rich and well-drained. The characteristics physicochemical measured the 0.0 a $0.2 \mathrm{~m}$ depth is shown in the Table 2 .

\subsection{Description of the Production System}

The first operation carried out by the farmers in the settlement was the lodging and desiccation of existing vegetation in the area where the sorghum was planted. The herbicide used was Glyphosate at a dose of $2.5 \mathrm{~L} \cdot \mathrm{ha}^{-1}$ applied initially in the preparation phase of the area for planting. The prepared by mixing one litre of the herbicide in 100 litres of water, and applied with a 600 litre Jacto mechanical sprayer, driven by a $75 \mathrm{hp}$ Massey Fergusson 296 tractor. 
Table 1. Characteristics of the climate in the study area.

\begin{tabular}{ccc}
\hline Parameter & Value & Unit \\
\hline Mean annual insolation & 3068.5 & h.year \\
Mean annual potential evaporation & 1798.8 & $\mathrm{~mm} \cdot \mathrm{year}^{-1}$ \\
Mean annual maximum temperature & 33.5 & ${ }^{\circ} \mathrm{C}$ \\
Mean annual temperature & 27.7 & ${ }^{\circ} \mathrm{C}$ \\
Mean annual minimum temperature & 23.3 & ${ }^{\circ} \mathrm{C}$ \\
Mean annual relative humidity & 71.5 & $\%$ \\
Mean annual wind speed & 3.6 & $\mathrm{~m} \cdot \mathrm{s}^{-1}$
\end{tabular}

Source: [13].

Table 2. Parameters physicochemical of soil of the area of rainfed agriculture.

\begin{tabular}{cc}
\hline Parameters physicochemical & Values \\
pH & 7.2 \\
Density & $1.34 \mathrm{~g} \cdot \mathrm{cm}^{-3}$ \\
Clay & $263 \mathrm{~g} \cdot \mathrm{kg}^{-1}$ \\
Silte & $175 \mathrm{~g} \cdot \mathrm{kg}^{-1}$ \\
Sand & $562 \mathrm{~g} \cdot \mathrm{kg}^{-1}$ \\
M.O & $20.89 \mathrm{~g} \cdot \mathrm{kg}^{-1}$ \\
K & $17.61 \mathrm{mmol} \mathrm{dm}^{-3}$ \\
Mg & $27.0 \mathrm{mmol} \mathrm{dm}^{-3}$ \\
$\mathrm{Ca}$ & $96.0 \mathrm{mmol} \mathrm{dm}^{-3}$ \\
$\mathrm{H}+\mathrm{Al}$ & $13.6 \mathrm{mmol} \mathrm{dm}^{-3}$ \\
$\mathrm{P}$ & $45.0{\mathrm{mg} \cdot \mathrm{dm}^{-3}}^{\mathrm{Cu}}$ \\
$\mathrm{Mn}$ & $2.60 \mathrm{mg} \cdot \mathrm{dm}^{-3}$ \\
$\mathrm{Fe}$ & $81.00 \mathrm{mg} \cdot \mathrm{dm}^{-3}$ \\
$\mathrm{~B}$ & $5.08 \mathrm{mg} \cdot \mathrm{dm}^{-3}$ \\
$\mathrm{Zn}$ & $0.11 \mathrm{mg} \cdot \mathrm{dm}^{-3}$ \\
& $2.50 \mathrm{mg} \cdot \mathrm{dm}^{-3}$ \\
\hline
\end{tabular}

Source: [14].

The second operation was planting, using seeds of the sorghum hybrid "BR 304". This was carried out under a system of direct seeding, using a model SP Light 3000 Baldanseeder, driven by a 75 hp Valtra 785 tractor. Planting was performed eight days after application of the herbicide, at a depth of 5 to $6 \mathrm{~cm}$, and with 6 to 7 seeds per linear metre, at a spacing between rows of $0.45 \mathrm{~m}$, giving a population of around 133,332 to 155,554 plants $\mathrm{ha}^{-1}$. Germination took place between 5 to 8 days after sowing.

The BR 304 is a simple hybrid, a result of the crossroad of lineage BR 001A with BR $012 \mathrm{R}$, cycle of approximately 125 days. BR 304 is tolerant to the dry 
stem rot, caused by the pathogen Macrophomina phaseolina, under conditions of water deficiency. This characteristic becomes the BR 304 highly recommended for planting in succession to precose summer crops and late plantings. It is recommended for the Northeast, Midwest, Southeast and South regions, especially for times when rainfall is lower [15].

Finally, harvesting, like the other operations, was also carried out mechanically using a CASE IH, model 7130 harvester. All the stages were performed under conditions of soil and climate that were favourable to each agricultural operation, since, according to [16], tillage, sowing, cropping practices and harvesting should be carried out under adequate conditions of soil moisture, as they can cause a reduction in soil porosity and in the flow of liquid and gases, increase soil density, and consequently reduce crop productivity.

\subsection{Analysed Variables}

\subsubsection{Productivity of the Sorghum}

The mean productivity of the crop was analysed based on the ratio of sorghum production to the area of cultivation, as per Equation (1).

$$
\text { Pme }=\frac{p}{x}
$$

in which: Pme-Mean productivity $\left(\mathrm{kg} \cdot \mathrm{ha}^{-1}\right) ; \mathrm{p}-$ sorghum production $(\mathrm{kg}) ; \mathrm{x}-$ planted area (ha).

\subsubsection{Water-Use Efficiency}

Water-use efficiency (WUE) was obtained from the ratio of crop production to the volume of water applied, as per [17], Equation (2).

$$
\text { WUE }=\frac{\mathrm{p}}{\mathrm{v}}
$$

in which: WUE-water-use efficiency $\left(\mathrm{kg} \cdot \mathrm{m}^{-3}\right) ; \mathrm{p}$-crop production $(\mathrm{kg})$; $\mathrm{v}$ volume of water applied $\left(\mathrm{m}^{3}\right)$.

\subsubsection{Financial Analysis}

For the financial analysis, the methodology proposed by the Company for Technical Assistance and Rural Extension-EMATER-DF [18] was adopted, in which the financial concepts are defined by Equations (3)-(5). Given that total revenue refers to unit price multiplied by the quantity of produced goods.

$$
\mathrm{TR}=\text { Price } * \text { Quantity }
$$

in which: $\mathrm{TR}-\mathrm{Total}$ revenue $\left(\mathrm{BRL} \cdot \mathrm{ha}^{-1}\right)$.

The cost of production is the sum of the fixed and variable costs, i.e. all the expenses generated during cultivation of the sorghum, such as tillage, planting, crop treatments, herbicides, seeds and labour, among others (Equation (4)).

$$
\mathrm{Cp}=\mathrm{Cf}+\mathrm{Cv}
$$

in which: $\mathrm{Cp}-$ production costs (BRL); $\mathrm{Cf}-$ fixed costs (BRL); $\mathrm{Cv}-$ variable costs (BRL). 
Net revenue refers to gross revenue minus product returns and taxes paid by the company (Equation (5)).

$$
\mathrm{NR}=\mathrm{GR}-\mathrm{PE}-\mathrm{T}
$$

in which: $\mathrm{NR}$-net revenue (BRL); GR - gross revenue (BRL); PE-general expenses of the production process (BRL); $T$-taxes (BRL).

\subsection{Statistical Analysis}

Descriptive statistics were used to analyse the following parameters: mean, standard deviation and coefficient of variation. The data were analysed using the SPSS $\mathrm{v} 16$ software, with the Excel software being used for the graphs and regression analysis of the correlations between the different parameters under evaluation.

\section{Results and Discussion}

With the production data of the 12 lots of producers at the Grande Lagoa settlement, located in the semi-arid region of Brazil, values can be seen from the descriptive analysis, which vary from $438 \mathrm{~kg} \cdot \mathrm{ha}^{-1}$ to $2143 \mathrm{~kg} \cdot \mathrm{ha}^{-1}$, with a mean value of $919.42 \mathrm{~kg} \cdot \mathrm{ha}^{-1}$ and a coefficient of variation of $49 \%$ (Table 3). Although the coefficient of variation had a high value, $75 \%$ of the values for productivity are within the range of the mean \pm standard deviation $(919 \pm 469)$. Of all the lots under evaluation, $67 \%$ had lower productivity than the mean for the group, while $18 \%$ achieved a value for productivity statistically higher than the mean at a level of $5 \%$ probability.

The mean value for productivity found was lower than the values for productivity registered in other Brazilian states, including that of the state itself. According to a survey by [6], the highest production of sorghum, $4500 \mathrm{~kg} \cdot \mathrm{ha}^{-1}$, was found in the Federal District, and the lowest, $1006 \mathrm{~kg} \cdot \mathrm{ha}^{-1}$, was obtained in the State of Bahia. In the State of Ceará, the average value was $1346 \mathrm{~kg} \cdot \mathrm{ha}^{-1}$, for the 2015/2016 harvest.

Although the production lots received the same type of management, it can be seen from the coefficient of variation that productivity displayed high variability,

Table 3. Descriptive analysis of data for sorghum production.

\begin{tabular}{|c|c|c|}
\hline \multicolumn{2}{|c|}{ Parameter } & Value $\left(\mathrm{kg} \cdot \mathrm{ha}^{-1}\right)$ \\
\hline \multicolumn{2}{|c|}{ Mean } & 919.42 \\
\hline \multicolumn{2}{|c|}{ Mode } & 438.00 \\
\hline \multicolumn{2}{|c|}{ Median } & 739.00 \\
\hline \multicolumn{2}{|c|}{ Standard deviation } & 469.80 \\
\hline \multirow{2}{*}{ 95\% Confidence interval } & Lower limit & 620.92 \\
\hline & Upper limit & 1217.91 \\
\hline \multicolumn{2}{|c|}{ Minimum } & 438.00 \\
\hline \multicolumn{2}{|c|}{ Maximum } & 2143.00 \\
\hline
\end{tabular}


this being attributed to the spatial variability of the soil attributes, and especially the spatial and temporal variation of the rainfall.

According to [19] and [20], when analysing forage productivity in a Red Latosol they also found high variability (29\%), which was attributed to the spatial variability of the soil attributes. On the other hand, [21], studying the physical attributes of the soil, found that at both depths analysed, the coefficients of variation were classified as low, medium, high and very high, ranging from $10.7 \%$ to $32.9 \%$.

As regards the data for sorghum production and productivity for each of the lots in the settlement (Table 4), it was found that lots $02,03,04$ and 12 displayed higher values for productivity. This fact is attributed to the time of planting, since, especially in the case of rainfed agriculture, planning the agricultural calendar to take better advantage of the rainfall is a prime factor in the viability of a production system.

The low productivity and high variability are related to the distribution of rainfall during the period the sorghum was under cultivation, since the greatest limitation on agricultural production is not expressed by the total rainfall, but by the uncertainty of how these events are distributed over time, as well as the constant occurrence of periods with no rainfall (hot and dry) during the rainy season. According to [22], and [23], these hot, dry spells are characterised as an area of climate vulnerability for agricultural sustainability.

According to [24] and [25] further point out that although water is the limiting factor in agricultural production, the distribution of rainfall events over time and space is what most affects crop development and agricultural production. As found in a study by [26], the low productivity seen in crops of forage sorghum on small farms in the north of the State of Minas Gerais is mainly due to the irregular distribution and low volume of rainfall during the development cycle of the sorghum.

Table 4. Sorghum production and productivity for each lot.

\begin{tabular}{ccccc}
\hline Lot & Planted Area (ha) & Date of Planting & Production $(\mathrm{kg})$ & Productivity $\left(\mathrm{kg} \cdot \mathrm{ha}^{-1}\right)$ \\
\hline 01 & 8.62 & 12 May & 8100 & 940 \\
02 & 15.00 & 01 April & 15,480 & 1032 \\
03 & 12.90 & 27 April & 14,220 & 1102 \\
04 & 4.48 & 20 April & 9600 & 2143 \\
05 & 8.35 & 22 May & 3660 & 438 \\
06 & 10.67 & 03 June & 5640 & 529 \\
07 & 4.80 & 03 June & 2880 & 600 \\
08 & 18.25 & 17 May & 11,220 & 701 \\
09 & 22.05 & 10 May & 15,720 & 713 \\
10 & 16.38 & 02 June & 10,020 & 595 \\
11 & 8.11 & 17 May & 7080 & 873 \\
12 & 9.00 & 26 April & 12,300 & 1367 \\
\hline
\end{tabular}


Regarding daily and monthly rainfall occurring in the study area during cultivation, these can be seen in Figure 2, where the highest values of 300 and 280 $\mathrm{mm}$ were recorded in March and April respectively, equivalent to $62 \%$ of the total rainfall, characterising the irregularity of rainfall distribution in the region.

Planting was concentrated from 1 April to 3 June, when rainfall during the growing season was $857 \mathrm{~mm}$. It is noteworthy that from January to July, rainfall exceeded both the regional average of $790 \mathrm{~mm} \cdot \mathrm{year}^{-1}$ [12] and the historical average for the last 34 years, which was equal to $737 \mathrm{~mm}$ [27].

Similarly, [28] point out that the total rainfall in the rainy season is sufficient for the development of rainfed agriculture in the intertropical zone, albeit affected by hot, dry spells; a phenomenon characterised by periods when the rainfall is interrupted during the rainy season. [29] add that the problem of irregular rainfall in the Northeast results not only from variations in total rainfall, but also from the duration and intensity of that rainfall.

Table 5 therefore, shows the number of dry spells and the length of each such event during cultivation of the sorghum; by means of the planting date, it was possible to identify which lot had the most influence on productivity as a function of these events. Thus, lots that were sown in April were less influenced by these periods, but also because the rainfall depth for March provided greater soil moisture at the time of planting, resulting in consequently higher productivity in lots $04,12,03$ and 02 , where planting was carried out on 20, 26, 27 and 01 April respectively.

On the other hand, lots $05,06,07$ and 10 had lower values for productivity due to the time of planting, when they were influenced by the length of the dry spells, with six such periods being registered on average during cultivation, most

Table 5. Number of dry spells and duration of each event for the different Phenological stages of the crop in each lot.

\begin{tabular}{cccccccc}
\hline \multirow{2}{*}{ Lot } & Total Dry Spells & \multicolumn{3}{c}{ Phenological Stage } & \multicolumn{3}{c}{ Event Duration(days) } \\
\cline { 2 - 8 } & 7 & EC1 & EC2 & EC3 & EC1 & EC2 & EC3 \\
\hline 01 & 8 & 3 & 3 & 1 & 6 & 6 & 32 \\
02 & 6 & 2 & 3 & 3 & 5 & 6 & 5 \\
03 & 8 & 3 & 2 & 1 & 6 & 5 & 22 \\
04 & 6 & 3 & 2 & 3 & 5 & 6 & 8 \\
05 & 5 & 3 & 1 & 1 & 6 & 28 & 30 \\
06 & 5 & 3 & 1 & 1 & 6 & 28 & 30 \\
07 & 6 & 2 & 3 & 1 & 6 & 7 & 31 \\
08 & 6 & 2 & 3 & 1 & 6 & 6 & 36 \\
09 & 5 & 3 & 1 & 1 & 6 & 28 & 30 \\
10 & 5 & 2 & 3 & 1 & 6 & 7 & 31 \\
11 & 6 & 3 & 2 & 1 & 6 & 5 & 20 \\
12 & & & & & & & 31 \\
\hline
\end{tabular}




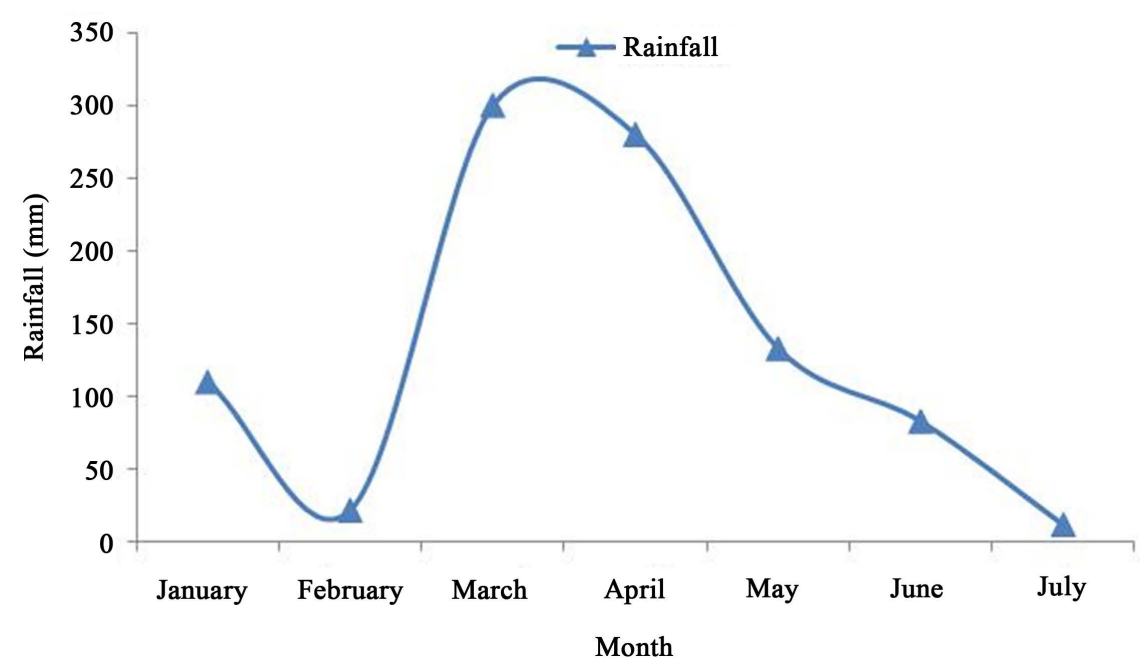

Figure 2. Monthly rainfall during the sorghum cycle.

of them of six to seven consecutive days with no rainfall, and one period of 30 days, which contributed significantly to the low values for productivity found in these lots.

According to [30], in a study in the State of Pernambuco in the semi-arid region of the Brazilian Northeast, found on average six to seven dry events per rainy season, with an average lack of rainfall of nine to eighteen days. However, longer dry spells of the order of 14 to 36 days were noted.

In addition to determining the number of dry spells that occurred, it was important to analyse the length of each event, as it was thereby possible to observe the high variability in productivity as a function of the spatial and temporal distribution of rainfall for each phenological stage of the crop, as well as the duration of the events for each physiological phase of the sorghum (Table 5).

Thus, it can be also be seen in Table 5 that during the first stage of crop growth (EC1), which runs from planting and germination to panicle initiation, approximately 30 days, there were around two to three dry spells, lasting from five to six days, in each lot; there was therefore no significant influence at this phenological stage for the low indices of productivity. However, the speed of germination, emergence and seedling establishment is important, since the plant is small, has slow initial growth, and at this stage, grain yield can be seriously reduced.

During the next stage (EC2), which includes panicle initiation to flowering, several growth processes, if affected, could compromise crop yield, among them, according to [15], leaf area and root system development, dry matter accumulation and the establishment of a potential number of seeds, the latter being probably the most critical production component associated with increased yield.

It was found that during the EC2 stage, which goes from day 30 to day 70 , there were on average two dry spells. However, it was the length of these events that had the most significant influence on the low productivity seen in lots 05 , 
06, 07 and 10, where the average length was 24 days. Whereas, for lots 02, 03, 04 and 12 , where the duration of these events was around 5 to 6 days, productivity was not significantly compromised.

For [31], any aggression to the plants at the EC2 stage, such as the undue application of agrochemicals or an unfavourable climatic event, such as a lack of soil moisture, will affect panicle emergence and compromise the final productivity of the crop.

During the third phase (EC3), which goes from flowering to physiological maturation and lasts a little more than 20 days, the factors considered the most important are those related to grain filling. At this stage, the plant continues to depend on a good level of water in the soil for adequate grain filling, with water deficiency during this period usually causing shrivelled grains and a fall in productivity [31]. It was found that lots with a low value for productivity were those that had an average of 30 days with no rainfall.

According to [23] point out that the hot, dry spells are a serious problem when they last longer than ten days without continuous rainfall, and especially when they affect the phenological stages of flowering and formation and of grain filling, stages EC2 and EC3 respectively; they are also harmful when they occur at the time of plant emergence, EC1. Therefore, comparing the data for productivity in Table 3 with the number of hot, dry spells in Table 5, a close relationship was seen between productivity and the occurrence of the dry spells, especially for the duration of these events.

Similarly, [32] point out that in rainfed production systems, the best use of the water resources is obtained by adjusting the time of sowing to the rainfall regime. According to [33], climatic variability can significantly affect crop yield, even when the crop is sown at a suitable time.

Predicting the occurrence of hot, dry spells and their duration is therefore quite important, since it provides additional information for the planning of both rainfed and irrigated agriculture, helping to maximize water-use efficiency in areas under cultivation [34].

\subsection{Water-Use Efficiency}

To calculate the volume of water per kilogram of sorghum produced in the rainfed system, the rainfall depth during the crop cycle and the total production of each lot were considered, and the amount of rainfall determined as a function of the area of each lot, as shown in Table 6.

It can be seen in Table 6 that water-use efficiency in the sorghum crop showed high variability as a natural result of the distribution of rainfall during the crop cycle in each lot, in addition to the variation in production values. The high value for lot 02 for the ratio of grain produced to water applied, of 4.83 $\mathrm{m}^{3} \cdot \mathrm{kg}^{-1}$, is explained by the input of a rainfall depth greater than that required by the crop, which is $300-325 \mathrm{~mm}$. The best ratio of $1.13 \mathrm{~m}^{3} \cdot \mathrm{kg}^{-1}$ was seen in lot 04, which displayed maximum productivity. 
Table 6. Water-use efficiency for each lot in the semi-arid region.

\begin{tabular}{cccccc}
\hline Lot & Area (ha) & Rainfall $(\mathrm{mm})$ & Volume $\left(\mathrm{m}^{3}\right)$ & Production $(\mathrm{kg})$ & WUE $\left(\mathrm{m}^{3} \cdot \mathrm{kg}^{-1}\right)$ \\
\hline 01 & 8.62 & 133 & 11,465 & 8100 & 1.41 \\
02 & 15.00 & 496 & 74,400 & 15,400 & 4.83 \\
03 & 12.90 & 243 & 31,347 & 14,220 & 2.20 \\
04 & 4.48 & 243 & 10,886 & 9600 & 1.13 \\
05 & 8.35 & 113 & 9435 & 3660 & 2.57 \\
06 & 10.67 & 95 & 10,137 & 5640 & 1.80 \\
07 & 4.80 & 95 & 4560 & 2880 & 1.59 \\
08 & 18.25 & 133 & 24,273 & 11,220 & 2.16 \\
09 & 22.05 & 182 & 40,131 & 15,720 & 2.55 \\
10 & 16.38 & 95 & 15,561 & 10,020 & 1.52 \\
11 & 8.11 & 133 & 10,786 & 7080 & 1.53 \\
12 & 9.00 & 243 & 21,870 & 12,300 & 1.78 \\
\hline
\end{tabular}

For [35], improving water-use efficiency is a key factor in the continuous increase in crop productivity in arid and semi-arid regions.

Thus, it was found that the best ratio of grain production to water demand shows a strong correlation with water distribution throughout the cycle, and not only with the total volume; according to [36], soil moisture conditions have a significant influence on water-use efficiency in arid and semi-arid regions. This fact demonstrates the great challenge of successful rainfed agriculture, where the irregularity of rainfall distribution was seen in this research as a limiting factor of greater weight than the actual volume of rainfall.

In their study, [37] found large variations in water-use efficiency in a crop of maize for the towns being studied, but found no direct relationship between grain yield and water-use efficiency in maize during the rainy season, or between rainfall and water productivity.

It is therefore necessary to adopt production systems that can adapt to this reality, as well as working together with meteorological agencies, taking advantage of rain forecasts, and adopting planting times in accordance with the information provided by such bodies.

\subsection{Financial Analysis}

For the financial analysis, the production costs per hectare of the sorghum crop were calculated, as shown in Table 7.

According to the data shown in Table 7, it was found that the cost of production for each hectare of planted sorghum was BRL 554.22, making a financial analysis of the system possible, as shown in Table 8.

According to the data shown in Table 8 , it can be seen that only lots 01,02 , 03, 04 and 12 presented positive economic results, especially lots $02,03,04$ and 12 , with a good return on the capital invested, of the order of $11 \%, 20 \%, 132 \%$ 
Table 7. Production costs for the sorghum crop.

\begin{tabular}{ccccc}
\hline Discrimination & Unit & Quantity & $\begin{array}{c}\text { Unit Price } \\
(\text { BRL })\end{array}$ & $\begin{array}{c}\text { Total Price } \\
(\text { BRL })\end{array}$ \\
\hline Seeds & Kg & 6 & 15.19 & 91.14 \\
Herbicide (Glyphosate) & L & 3 & 24.68 & 74.04 \\
Graphite & Kg & 0.03 & 5.00 & 0.15 \\
Empty 60 Kg bags & Bag & 40 & 0.70 & 28.00 \\
Foliar fertiliser & L & 3 & 22.00 & 66.00 \\
Subtotal & & & & 259.33 \\
Labour & & & & \\
Herbicideapplication & H/M & 0.5 & 88.60 & 44.30 \\
Planting & H/M & 1 & 88.60 & 88.60 \\
Harvesting & H/M & 1 & 91.25 & 91.25 \\
Bagging & Bag & 40 & 0.50 & 20.00 \\
Transport & Appropriation & 1 & 50.74 & 50.74 \\
& Subtotal & & & 294.89 \\
Total & & & 554.22 \\
\hline
\end{tabular}

Table 8. Financial analysis of the production system.

\begin{tabular}{ccccccc}
\hline Lot & $\begin{array}{c}\text { Area } \\
(\mathrm{ha})\end{array}$ & $\begin{array}{c}\text { Production } \\
(\mathbf{k g})\end{array}$ & $\begin{array}{c}\text { Average } \\
\text { Price } \\
\left(\mathbf{B R L ~ k g}^{-1}\right)\end{array}$ & $\begin{array}{c}\text { Total } \\
\text { Value } \\
(\mathrm{BRL})\end{array}$ & $\begin{array}{c}\text { Total } \\
\text { Cost } \\
(\text { BRL })\end{array}$ & $\begin{array}{c}\text { Profit } \\
(\mathrm{BRL})\end{array}$ \\
\hline 01 & 8.62 & 8100 & 0.60 & 4860.00 & 4777.38 & 82.62 \\
02 & 15.00 & 15,400 & 0.60 & 9240.00 & 8313.30 & 926.70 \\
03 & 12.90 & 14,220 & 0.60 & 8532.00 & 7149.44 & 1382.56 \\
04 & 4.48 & 9600 & 0.60 & 5760.00 & 2482.90 & 3277.10 \\
05 & 8.35 & 3660 & 0.60 & 2196.00 & 4644.36 & -2448.36 \\
06 & 10.67 & 5640 & 0.60 & 3384.00 & 5913.53 & -2529.53 \\
07 & 4.80 & 2880 & 0.60 & 1728.00 & 2660.25 & -932.25 \\
08 & 18.25 & 11,220 & 0.60 & 6732.00 & $10,297.40$ & -3565.40 \\
09 & 22.05 & 15,720 & 0.60 & 9432.00 & $12,220.55$ & -2788.55 \\
10 & 16.38 & 10,020 & 0.60 & 6012.00 & 9188.97 & -3176.97 \\
11 & 8.11 & 7080 & 0.60 & 4248.00 & 4494.72 & -246.72 \\
12 & 9.00 & 12,300 & 0.60 & 7380.00 & 4987.98 & 2392.02 \\
\hline
\end{tabular}

and $48 \%$ respectively. It is worth noting that these four lots were planted at the end of April, thereby suffering less influence from the hot, dry spells, allowing greater productivity of the sorghum, and consequently better economic return. 


\section{Conclusions}

The low productivity of the sorghum under rainfed conditions shows that the lack of success of production systems in semi-arid regions is not due to total rainfall, but rather the spatial and temporal distribution of the rainfall during the rainy season, since the lowest values for productivity were seen with the occurrence of a greater number and the greater duration of hot, dry spells during cultivation.

The maximum yields of $1032 \mathrm{~kg} \cdot \mathrm{ha}^{-1}$ (lot 02), $1102 \mathrm{~kg} \cdot \mathrm{ha}^{-1}$ (lot 03), 2143 $\mathrm{kg} \cdot \mathrm{ha}^{-1}$ (lot 04) and $1367 \mathrm{~kg} \cdot \mathrm{ha}^{-1}$ (lot 12) were recorded when planting was carried out on 1,27, 20 and 26 April respectively, when there were on average seven hot, dry spells of a shorter duration of around 8 days, while the lowest values for productivity occurred when planting was outside this period, with an average occurrence of six dry spells of a longer duration of around 17 days.

No direct relationship was found between grain yield and water-use efficiency in sorghum under rainfed conditions, or between rainfall and water productivity, since the best ratio of grain production to water demand shows a strong correlation with water distribution throughout the cycle and not only with the total volume.

Productivity under rainfed conditions is still low in some regions, requiring further research to determine the causes and set up strategies that would increase crop yield. This way, knowledge of the occurrence and duration of hot, dry spells, together with the time of planting of the sorghum, has the potential to approximate actual productivity to the productivity that can be achieved under a rainfed regime.

\section{Acknowledgements}

The authors acknowledge for financial support and the Coordination for the Improvement of Higher Education Personnel (CAPES) and Cearense Foundation of Scientific and Technological Support (FUNCAP). Thanks also go to the Secretary of Agrarian Development of the State of Ceará (SDA) and Association of Producers Irrigated Perimeter Curupati.

\section{Conflicts of Interest}

There are no conflicts of interest in present study.

\section{References}

[1] Awika, J.M. and Rooney, L.W. (2004) Sorghum Phytochemicals and Their Potential Aspects on Human Health. Phytochemistry, 65, 1199-1221.

[2] Mutisya, J., Sun, C., Rosenquist, S., Baguma, Y. and Jansson, C. (2009) Diurnal Oscillation of SBE Expression in Sorghum Endosperm. Journal of Plant Physiology, 166, 428-434. https://doi.org/10.1016/j.jplph.2008.06.017

[3] Dicko, M.H., Gruppen, H., Traoré, A.S., Castano, G., Menendez, R., Mas R., Voragen, A.J. and Berkel, W. (2006) Sorghum Grain as Human Food in Africa: Relevance of Content of Starch and Amylase Activities. African Journal of Biotechnology, 5, 384-395. 
[4] Rooney, L.W. and Awika, J.M. (2005) Overview of Products and Health Benefits of Specialty Sorghums. Cereal Foods World, 50, 109-115.

[5] USDA-United States Department of Agriculture. Foreign Agriculture Service, Production, Supply, and Distribution Database. https://www.usda.gov

[6] CONAB-National Supply Company. Crop 2015/2016. http://www.conab.gov.br/OlalaCMS/uploads/arquivos/16_04_07_10_39_11_boleti m_graos_abril_2016.pdf

[7] Nelson, D.R., West, C.T. and Finan, T.J. (2009) Introduction to "In focus: Global Change and Adaptation in Local Places”. American Anthropologist, 111, 271-274. https://doi.org/10.1111/j.1548-1433.2009.01131.x

[8] Guerreiro, M.J.S., Andrade, E.A., Abreu, I. and Lajinha, T. (2013) Long-Term Variation of Precipitation Indices in Ceará State, Northeast Brazil. International Journal of Climatology, 33, 2929-2939. https://doi.org/10.1002/joc.3645

[9] Alves, J.M.B., Servain, J. and Campos, J.N.B. (2009) Relationship between Ocean Climatic Variability and Rainfed Agriculture in Northeast Brazil. Climate Research, 38, 225-236. https://doi.org/10.3354/cr00786

[10] INSA-National Institute of the Semiarid. Population of the Semi-Arid. http://www.insa.gov.br

[11] Venkateswarlu, B. and Prasad, J.V.N.S. (2012) Carrying Capacity of Indian Agriculture: Issues Related to Rainfed Farming. Current Science, 102, 882-888.

[12] Institute of Economic Research and Strategy of Ceará (2015) Ceará in Maps. www.ipece.ce.gov.br

[13] National Institute of Meteorology Climatology (2017) Maps. http://www.inmet.gov.br

[14] Costa, S.C., Soares, A.A., Sediyama, G.C., Viana, T.V.A. and Moreira, F.V.O. (2011) Variation of Physical and Chemical Parameters of Fruit Fruits in 'Pacovan' Subjected to Different Irrigation Blades and Doses Potassium in Chapada do ApodiLimoeiro do Norte-Ce. Irriga, Botucatu, 16, 82-92. https://doi.org/10.15809/irriga.2011v16n1p82

[15] Magalhães, P.C., Durães, F.O.M. and Rodrigues, J.A.S. (2008) Cultivation of Sorghum: Ecophysiology. 4th Edition, Embrapa Milho e Sorgo, Sete Lagoas.

[16] Basso, F.C., Andreotti, M., Carvalho, M.P. and Lodo, B.N. (2011) Relationship between Forage Sorghum Yield and Physical Attributes and Organic Matter Content Latosol at the Cerrado. Pesquisa Agropecuária Tropical, 41, 135-144. https://doi.org/10.5216/pat.v41i1.7099

[17] Loomis, R.S. (1983) Crop Manipulations for Efficient Use of Water: An Overview. In: Taylor, H.M., Jordan, W.R. and Sinclair, T.R., Eds., Limitations to Efficient Water Use in Crop Production, American Society of Agronomy, Crop Society of America, and Soil Science Society of America, Madison, 345-374.

[18] Emater, D.F. (2009) Technical Assistance and Rural Extension of Distrito Federal. http://www.emater.df.gov.br/index.php?option=com_content\&view=article\&id=75 \&Itemid $=87$

[19] Pariz, C.M., Carvalho, M.P., Chioderoli, C.A., Nakayama, F.T., Andreotti, M. and Montanari, R. (2011) Spatial Variability of Forage Yield and Soil Physical Attributes of a Brachiaria Decumbens Pasture in the Brazilian Cerrado. Revista Brasileira de Zootecnia, 40, 2111-2120. http://dx.doi.org/10.1590/S1516-35982011001000007

[20] Montanari, R., Zambianco, E.C., Corrêa, A.R., Pellin, D.M.P., Carvalho, M.P. and Dalchiavon, F.C. (2012) Physical Attributes of a Red Latosol Correlated Linearly 
and Spatially with the Consortium of Pigeon Pea with Millet. Ceres, 59, 125-135. http://dx.doi.org/10.1590/S0034-737X2012000100018

[21] Freddi, O.S., Carvalho, M.P., Veronesi Júnior, V. and Carvalho, G.J. (2006) Productivity of Maize Related to Mechanical Resistance to Soil Penetration under Conventional Tillage. Revista de Engenharia Agrícola, 26, 113-121. http://dx.doi.org/10.1590/S0100-69162006000100013

[22] Duque, J.G. (1973) The Northeast and the Xerophilous Crops. 2nd Edition, Northeast Bank, Lewiston, 238.

[23] Silva, F.A.S. and Rao, T.V.R. (2002) Regimes Rainfall, Rainy Season and Probability of Occurrence of Dry Spells in the State of Ceará. Revista Brasileira de Engenharia Agrícola e Ambiental, 6, 453-459.

http://dx.doi.org/10.1590/S1415-43662002000300010

[24] Barron, J., Rockstrom, J., Gichuki, F. and Hatibu, N. (2003) Dry Spell Analysis and Maize Yields for Two Semiarid Locations in East Africa. Agricultural and Forest Meteorology, 117, 23-37. https://doi.org/10.1016/S0168-1923(03)00037-6

[25] Goenster, S., Wiehle, M., Gebauer, J., Mohamed, A.A., Stern, R.D. and Buerkert, A. (2015) Daily Rainfall Data to Identify Trends in Rainfall Amount and Rainfall Induced Agricultural Events in the Nuba Mountains of Sudan. Journal of Arid Environments, 22, 16-26. https://doi.org/10.1016/j.jaridenv.2015.06.003

[26] Neto, O.A., Caxito, A.M., Chaves, F.F. and Pessoa, S.T. (2016) Production Silage Brs Ponta Negra Sorghum in Small Farms in the North of Minas Gerais. Proceedings of 31 st Congresso Nacional de Milho e Sorgo "Milho e Sorgo: Inovações, Mercados e Segurança Alimentar”, Bento Gonçalves, 25-29 September 2016, 181-185.

[27] Foundation of Meteorology and Water Resources (2016) Historic Serie. http://www.funceme.br

[28] Carvalho, D.F., Faria, R.A., Sousa, S.A.V. and Borges, H.Q. (2000) Spatialization of the Dry Spell Period for Different Levels of Loss of Production in Maize Rio Verde Grande, MG. Revista Brasileira de Engenharia Agrícola e Ambiental, 4, 172-176. http://dx.doi.org/10.1590/S1415-43662000000200007

[29] Silva, L.L., Costa, R.F., Campos, J.H.B.C. and Dantas, R.T. (2009) Influence of Precipitation on Agricultural Productivity in the State of Paraíba. Revista Brasileira de Engenharia Agrícola e Ambiental, 13, 454-461. http://dx.doi.org/10.1590/S1415-43662009000400013

[30] Soares, D.B. and Nóbrega, R.S. (2010) Analysis Spatial and Climatological of the Occurrence of Dry Spell in the Pernambuco. Recife, PE. Revista de Geografia, 27, 95-106.

[31] Ribas, P.M. (2008) Cultivation of Sorghum: Planting. 4th Edition, Embrapa Milho e Sorgo, Sete Lagoas.

[32] Soler, C.M.T., Sentelhas, P.C. and Hoogenboom, G. (2007) Application of the CSM CERES-Maize Mode for Planting Date Evaluation and Yield Forecasting for Maize Grown Offseason in a Subtropical Environment. European Journal of Agronomy, 27, 165-177. https://doi.org/10.1016/j.eja.2007.03.002

[33] Andrade, C.L.T., Amaral, T.N., Silva, D.F., Garcia, A., Hoogenboom, G., Brito, R.A.L., Borges Júnior, J.C.F. and Gomide, R.L. (2009) Using the Ceres Maize Model as a Tool in the Definition of Maize Sowing Strategies: 3-Water Requirement and Productivity. Proceedings of XVI Congresso de Agrometeorologia, Belo Horizonte, 22-25 September 2009, 1528-1532.

[34] Carvalho, D.F., Oliveira, M.A.A., Sousa, S.A.V. and Carvalho, P.O.L. (1999) Estimates of Occurrences of Dry Spell in Seropédica, Vassouras e Piraí (RJ), and Influence on Yield of Bean (Phaseolus vulgaris L.). Ciência e Agrotecnologia, 23, 323-330. 
[35] Xiao, G.J., Zhang, F.J., Huang, J.Y., Luo, C.K., Wang, J., Ma, F., Yao, Y.B., Wang, R.Y. and Qiu, Z.J. (2016) Response of Bean Cultures' Water Use Efficiency against Climate Warming in Semiarid Regions of China. Agricultural Water Management, 173, 84-90. https://doi.org/10.1016/j.agwat.2016.05.010

[36] Tenhunen, J., Roupsard, O. and Rambal, S. (2002) Severe Drought Effects on Ecosystem $\mathrm{CO}_{2}$ and $\mathrm{H}_{2} \mathrm{O}$ Fluxes at Three Mediterranean Evergreen Sites: Revision of Current Hypotheses. Global Change Biology, 8, 999-1017.

https://doi.org/10.1046/j.1365-2486.2002.00530.x

[37] Correia, C.A., Andrade, C.L.T., Silva, P.P.G. and Magalhães, B.G. (2016) Simulation of Water Productivity for Rainfed Corn in Municipalities of Minas Gerais. Proceedings of 31 st Congresso Nacional de Milho e Sorgo "Milho e Sorgo: Inovações, Mercados e Segurança Alimentar", Bento Gonçalves, 25-29 September 2016, 1200 1203.

Submit or recommend next manuscript to SCIRP and we will provide best service for you:

Accepting pre-submission inquiries through Email, Facebook, LinkedIn, Twitter, etc. A wide selection of journals (inclusive of 9 subjects, more than 200 journals)

Providing 24-hour high-quality service

User-friendly online submission system

Fair and swift peer-review system

Efficient typesetting and proofreading procedure

Display of the result of downloads and visits, as well as the number of cited articles Maximum dissemination of your research work

Submit your manuscript at: http://papersubmission.scirp.org/

Or contact ajps@scirp.org 